Cornell Law Library

Scholarship@Cornell Law: A Digital Repository

Cornell Law Faculty Publications

Faculty Scholarship

$1-1-1993$

\title{
Harmonisation of Trade Laws in the African Economic Community
}

Muna Ndulo

Cornell Law School, mbn5@cornell.edu

Follow this and additional works at: http://scholarship.law.cornell.edu/facpub

Part of the Antitrust and Trade Regulation Commons

\section{Recommended Citation}

Ndulo, Muna, "Harmonisation of Trade Laws in the African Economic Community" (1993). Cornell Law Faculty Publications. Paper 65 .

http://scholarship.law.cornell.edu/facpub/65

This Article is brought to you for free and open access by the Faculty Scholarship at Scholarship@Cornell Law: A Digital Repository. It has been accepted for inclusion in Cornell Law Faculty Publications by an authorized administrator of Scholarship@Cornell Law: A Digital Repository. For more information, please contact jmp8@cornell.edu. 


\title{
HARMONISATION OF TRADE LAWS IN THE AFRICAN ECONOMIC COMMUNITY
}

\author{
Muna Ndulo*
}

\section{INTRODUCTION}

AfRICAN countries attained independence with high expectations. Most people believed that rapid progress would be made in raising incomes and improving the welfare of the African people. In the early years of independence many African countries successfully expanded their basic infrastructure and social services. After an initial period of growth, however, most economies faltered, then went into decline.' There are some exceptions but, in general, sub-Saharan Africa, as a whole, has now witnessed almost a decade of falling per capita incomes, increasing hunger and accelerating ecological degradation. The earlier progress made in social development is now being eroded. Overall, Africans are said to be

almost as poor today as they were 30 years ago. ${ }^{2}$ The severe economic crisis in Africa has inspired many African governments and institutions to review their strategies for development, with a view to taking measures to arrest the ever-worsening crisis. ${ }^{3}$

One such measure is the recently adopted Treaty establishing the African Economic Community. The Treaty was adopted at the Organisation of African Unity (OAU) Heads of States Meeting in Abuja, Nigeria, on 3 June 1991. ${ }^{+}$The Treaty establishes the African Economic Community. The objectives of the Community, as set out in Article 4 of the Treaty, are as follows: (a) to promote economic, social and cultural development and the integration of African economies in order to

\footnotetext{
* Advocate of the High Court and Supreme Court of Zambia. Legal Officer. International Trade Law Branch. Office of Legal Affairs, United Nations, formerly Professor, Dean of Law. University of Zambia, and visiting Professor. Cornell University (USA). The views expressed herein are those of the author and do not necessarily reflect the views of the United Nations.

1. See generally Sub-Saharan Africa: From Crisis to Sustainable Growth World Bank Report (1989). for a detailed study of the condition of sub-Saharan African cconomies. See also African Alternative Framework to Structural Adjustment Programmes for Social-Economic Recovery and Transformation (AAF-SAF). United Nations Economic Commission for Africa (E/ECA/CM.15/6/Rev. 3).

2. Sub-Saharan Africa, idem. chap.1. "A Thirty-Ycar perspective: Past and Future", p.16.

3. Sec AAF-SAF. op. cit. supra n.1. See also Pierre-Clasver. "Development Strategies-Lessons from Experience" African Leadership Forum (Ota, Nigeria, 1988).

4. Organisation of African Unity. Treaty Establishing the African Economic Community, adopted at Abuja, on June 3, 1991.
} 
increase economic self-reliance and an indigenous and self-sustained development; (b) to establish, on a continental scale, a framework for the development, mobilisation and utilisation of the human and material resources of Africa in order to achieve a self-reliant development; (c) to promote co-operation in all fields of human endeavour in order to raise the standard of living of African peoples and maintain and enhance economic stability, foster close and peaceful relations among member States and contribute to the progress, development and the economic integration of the continent; and (d) to co-ordinate and harmonise policies among existing economic communities in order to foster the gradual establishment of the Community. The Community, as can be seen from the goals it seeks to achieve, is not simply a trading arrangement or a mechanism for promoting co-operation in production based on the creation of a common market. In addition to integration of national markets and co-operation in production, the States joining the Community also undertake to co-operate with each other in certain functional areas, e.g. social, political, financial and monetary matters.

In Article 4(2) the Treaty establishing the African Economic Community provides several ways through which the objectives of the Treaty are to be achieved. Among them are the liberalisation of trade through the abolition, among member States, of non-tariff barriers in order to establish a free-trade area; the relaxation and eventual abolition of qualitative and administrative restrictions and the gradual evolution of a common trade policy; and the gradual removal, from member States, of obstacles to the free movement of persons, goods, services and capital and the right of residence and establishment. ${ }^{5}$ Among the non-tariff barriers to intraAfrican trade that the African Economic Community must confront must rank the present significantly diverse legal systems that exist in Africa. The membership of the Community represents at least four main legal systems, namely those of common law, Roman-Dutch law, Islamic law and civil law origin. Each, in turn, comprises many different systems of law, especially including traditional customary laws. Every country has its own legal traditions, its own system of legal thought, its own method of law-making and its own process of judicial determination of disputes."

Several articles in the Treaty require member States to take measures to eliminate customs duties, other restrictions or prohibitions, administrative and other non-tariff barriers. They also require adoption by member States of a common external customs tariff. ${ }^{7}$ Among the prob-

5. See Treaty Establishing the African Economic Community, supra n.4.

6. These differences exist often even in the smaller regional groupings. See M. Ndulo, The United Nations Convention on Contracts for the International Sale of Goods (1980) and "The Eastern and Southern African Preferential Trade Area" (1987) 3(2) Lesotho Law Journal 127.

7. Sec Arts.30. 31. and 32. Treaty Establishing the African Economic Community, supra n.4. 
lems that would probably require immediate attention in the free trade area are many related to the implementation of these provisions. The negotiations and regulations for the reduction of tariffs will inevitably be complex. Implementation will require the development of normative rules to give effect to the decisions. These rules will, in turn, have to be assimilated into the laws of member States. This will require a great effort in the harmonisation of Community trade laws that obstruct trade and not just those, for instance, limited to customs regulations. This raises the question whether the Community Treaty has created an institutional framework, within which there would exist a body with a clear mandate and capacity to undertake the complex task of harmonising Community trade laws, which could spearhead the creation of a physical, technical and legal infrastructure that would support regional exchanges in goods, services, labour and capital.

This article examines the topic of harmonisation of trade law in the African Economic Community and the factors that militate against African economic integration. It deals with the issue in six sections. The first section examines obstacles to African economic integration; the second explores the modalities for the establishment of the Community, while the third discusses the case for the harmonisation of Community trade laws. In the fourth section techniques that could be used to harmonise law and ways of assimilating Community law into the laws of member States are examined; the fifth section looks at the relevance of the work of international organisations to the harmonisation process in the Community and in the sixth section the article considers whether the Treaty has adequately dealt with the question of providing for an institutional framework to address the issue of the harmonisation of trade laws.

\section{OBSTACLES TO AFRICAN ECONOMIC INTEGRATION}

AFRICAN leaders have long recognised the need for closer regional ties as a way to overcome the fragmentation of the continent, one of the major constraints to its economic development. Economic integration is perceived by many African leaders and governments as a promising vehicle for enhancing economic and social development in their respective countries. The idea is reinforced by the relatively successful experiences of integration between Western European countries, the United StatesCanadian Free Trade Agreement and other integration schemes among countries in Latin America and in the Pacific and Asian region. Regional co-operation can help to promote a more complementary and sustained development of African countries, through the reinforcement of the regional infrastructure, a more efficient system of payment, greater access to credit, a more interrelated institutional system, a greater mutual awareness among economic agents operating in the different countries and, above all, through a growing technical complementarity and a 
greater development and integration of the productive sectors of African countries. The economic integration of Africa was a central theme of the 1980 Lagos Plan of Action, the Special United Nations Session on Africa in 1986 and numerous other high-level statements and reports on African policy and development strategy. ${ }^{8}$

There are currently several African integration schemes. These include the West African Economic Community (CEAO), the Preferential Trade Area for Eastern and Southern African States (PTA), the Economic Community of West African States (ECOWAS), the Southern African Development Community (SADC), the Central African Customs and Economic Union (EDEAC), the African and Mauritian Common Organisation (OCAM); the Comité Permanent Consultatif du Maghreb (CPCM); the Economic Community of the Great Lakes Countries (CEPGL), and one may add the South African Customs Union (SACU). Most of these schemes have achieved very little. ${ }^{y}$ The traditional explanation of the failure of integration schemes in Africa is that there is a lack of the political will necessary to see integration succeed, expressed in the chronic non-observance of commitments undertaken within the respective agreements and in the insufficient use of the instruments set up by those agreements. To seek the causes of the weakening of integration solely in the functioning of the regional or sub-regional institutions, or in the legal instruments governing them, would undoubtedly be to take an inadequate view of its complex and diverse nature. The differences in approach by various States to the solution of such acute problems as balance of payments difficulties are as responsible for the failure of these schemes as the incorrect design of the schemes themselves and the inadequacy of the traditional instruments, based on trade liberalisation, in helping to solve the current problems of economic development in Africa.

There are several factors that militate against economic integration in Africa. The economic nationalism that was strong at independence has left its mark. Many countries seem to go into economic integration agreements without any intention of parting with some measure of national sovereignty. In the past, membership of these groupings has been sought both as a sign of being a good African and as a way to obtain external development assistance. African States have to accept that

8. The Lagos Plan of Action was adopted in 1980 and its central theme was regional integration. It called for the establishment of an African Economic Community by the year 2000. See Organisation of African Unity Lagos Plan of Action for the Implementation of the Monrovia Strategy for the Economic Development of Africa (Lagos, April 1981).

9. The Economic Commission for Africa has noted: "Since the adoption of the Lagos Plan of Action and the Final Act of Lagos by African Heads of State and Government in 1980, Africa's efforts to bring about fundamental social-economic structural changes have been constantly frustrated". See AAF-SAF, op. cit. supra n.1, p.1. 
membership of an economic community has serious long-term implications for the States involved. It entails very close co-operation with one's neighbours and very often the adherence to traditional rivalry and differences impede the integration process. Differences in linguistic, political, legal and administrative systems have to be overcome. There is the problem of low priority being accorded to the implementation of integration programmes $v i s-\grave{a}$-vis national ones, which are very often supported and financed by influential international institutions such as the IMF and the World Bank. For example, under the structural adjustment programmes in place in most African States, domestic considerations take precedence over sub-regional integration preoccupations.

The economic infrastructure is inadequate to support economic integration. For instance, one of the major constraints on the growth and development of inter-African trade has been the inadequacy of payment and financial systems. Increased African trade will need finance and financial instruments such as banking networks providing letters of credit, export credits and other financial services. Diversified currency exchange regimes and payment restrictions prevail in Africa. Integration will require the adoption of collective policy measures to facilitate the liberalisation of payment and exchange restrictions and to enhance the convertability of national currencies.

The existence of border conflicts, linguistic rivalries (especially between English and French), compounded by racial suspicion on the continent between black Africans and Arab Africans can hamper economic integration. The hostile world economic environment has meant that many of the region's States are preoccupied with short-term recovery. There is also the lack of an acclaimed integration leader in the region with impeccable credentials such as a domestic economic track record of monetary and financial stability, diligent implementation of community programmes, a willingness to assume necessary responsibilities and a dominant position in regional trade and finance.

However, no matter how good the arguments and intentions to integrate may look on paper, the political environment for their implementation and preservation must be right for the effort to succeed. Economic co-operation and integration flourish better in an environment that is politically peaceful and stable. The examples of successful economic integration drawn from history clearly illustrate that they are predicated primarily upon a common outlook to political affairs among the community members. The locus classicus for such peace and stability is freedom for the individual. It is a happy development that the winds of democratisation and political reform now blowing across several regions of the world have not excluded Africa. Democracy is the ultimate guarantor of freedom of movement of goods and capital. We are now witnessing a period of transition from dictatorships to popular democracies in several States on the continent. Mutual respect and trust are expected to 
be fully restored between these newly emerging democratic leaderships and this will no doubt contribute to the advancement of regional cooperation and eventual economic integration. In addition, most of these schemes have achieved very little, partly because they lack a regulatory framework, and tariffs and non-tariff barriers to trade have not been reduced. The tempo and mode of integration basically depend on the development strategies and external linkages adopted by the States participating in the process. If the ambitious goal of creating an African Economic Community is going to be achieved, bolder efforts than have hitherto been made will be needed to deal with the problems outlined above and thereby create an enabling environment for an economic community to flourish.

\section{MODALITIES FOR THE ESTABLISHMENT OF THE COMMUNITY}

ARTICLE 6 of the Treaty sets out the modalities for the establishment of the Community, spanning a period of 34 years. There are six stages to pass through to achieve the ultimate goal of a community. The first stage will be devoted to the strengthening of existing regional economic communities such as the PTA and ECOWAS, and to establishing similar economic communities in those regions where none exist. The second stage will be to stabilise tariff and non-tariff barriers, customs duties and internal taxes. The third stage is the establishment of a free trade area. During this period a common external tariff is expected to be adopted and a customs union created. The fourth stage will aim at the furtherance of a customs union; the fifth is devoted to the establishment of the African Common Market, while the sixth and final stage will be devoted to consolidation and strengthening of the African Common Market. All these stages have been allocated specific time periods. There is, however, provision in the Treaty for the Assembly of Heads of State and Government to determine at the end of each stage whether expectations have been sufficiently fulfilled to enable a transition to the next stage. In short, a particular stage may be extended beyond the period specified by Article $6(2)$, provided that the entire six transitional periods do not exceed a period of 40 years.

The Treaty establishes several organs for the Community. In Article 8 they are set out as (a) the Assembly of Heads of States; (b) the Council of Ministers; (c) the Pan-African Parliament; (d) the Economic and Social Commission; (e) the Court of Justice; (f) the General Secretariat and (g) the specialised Technical Committees. The Court of Justice is set up by Article 18 of the Treaty. It is charged with ensuring adherence to the law in the interpretation and application of the Treaty. It is also empowered to decide on disputes submitted to it pursuant to the Treaty. It has the power to decide on actions brought by a member State or the Assembly on grounds of a violation of the provisions of the Treaty, or on grounds of 
lack of competence or abuse of powers by an organ, an authority or a member State; and it may, at the request of the Assembly or Council, give advisory opinions. The Assembly may further confer on the Court of Justice the power to assume jurisdiction by virtue of the Treaty over any disputes other than those referred to in paragraph 3(a) of Article 18. Article 19 states that the decisions of the Court of Justice are binding on member States and organs of the Community. There are several problems that will have to be overcome for such a Court to be effective. Among them, the diversity of the legal systems in Africa requires that careful attention will have to be paid to the evolution of legal procedures that will be acceptable to all member States. There is also the problem of enforcement of the orders of the Court. Historically, African States have openly resisted the resort to binding court procedures. There will therefore be a need for African States to cultivate respect for court decisions. The Court will also have to be adequately financed and in such a manner that its independence is secure so that it can render decisions without fear. Perhaps the most severe limitation on the effectiveness of the Court is the fact that, in accordance with Article 18(3), it can only act at the request of the Assembly of the Heads of State, the Council of Ministers or a member State. It could be argued that Article 18(4), in permitting the Assembly of Heads of States to confer on the Court of Justice power to assume jurisdiction by virtue of the Treaty over any dispute other than those referred to in Article 18(3), allows the Court to hear actions brought by individuals and corporate entities. The weakness of this provision, however, is that it is not to be the case unless the Assembly positively decides to confer that power on the Court. This is not a satisfactory solution. Experience in the European Community has shown that private individuals and corporate entities can be effective guardians of a community treaty and its laws.

\section{HARMONISATION OF TRADE LAWS IN THE COMMUNITY}

THE harmonisation of trade laws and commercial practices is an important ingredient of regional integration, without which meaningful economic integration cannot be achieved. Economic integration needs a legal framework to foster and support it. It is widely recognised that conflicts and divergences arising from the laws of different States in matters relating to international trade constitute an obstacle to the development of that trade. "'The existence, in Africa, of widely accepted trade

10. The study that led to the establishment of UNCITRAL referred to difficulties faced by parties engaging in international commercial transactions as a result of the multiplicity of and divergences in national laws and recommended a new UN organ to systematise and accelerate the process of harmonisation and unification of international trade law. See "Progressive development of the law of international trade: report of the SecretaryGeneral", Official Records of the General Assembly. Twenty-first Session, Annexes, agenda item 88, docs.A/6396, Add. 1 and 2. 
laws and commercial practices would eliminate a number of problems which currently plague intraregional trade. One of the problems traders face is the diversity of national laws and the complexity of the rules of private international law for determining which system applies to their transaction, which, even if based on the choice of the parties, would have to contend with limitations imposed by individual States. Presently in Africa the parties cannot always be certain which law will apply. This may make them less inclined to enter into intraregional commercial transactions. If the parties in an intraregional business transaction come from different States and are therefore accustomed to different legal systems, the governing law is going to be unfamiliar to one of the parties. This, in turn, may also discourage parties from entering into intraregional trade." The absence of uniform commercial rules makes the outcome of litigation unpredictable and to some extent dependent on the court and place of hearing of the case. The problem is compounded by the fact that these laws are often inadequate to deal with issues arising from intraregional transactions since they were usually designed to regulate domestic transactions. ${ }^{12}$

In the absence of a supranational, all-embracing mercantile legal system, intraregional traders can, and do, choose between the national legal systems by indicating in the contract the one which they want to govern the contractual relationship. The concept of party autonomy is common to most systems of law and permits the parties, within limits, to choose the proper or governing law of a contract. A choice of law clause, however, is not always a practical solution to the problems presented in intraregional trade. Very often contracts fail to specify which law applies because of an impasse over this delicate question, or because it is overlooked in the need for speed in concluding a contract. In these cases, a buyer or seller will not be able to determine which law will apply until he or she completes a detailed conflicts of law analysis to determine which law has the closest relationship to the transaction. When this analysis suggests that the law of a given State other than his or her own may apply, the buyer or seller must then go through the difficult process of researching the law of the State to determine his or her rights and obligations. This is particularly problematic in Africa because access to another State's

11. UNCTAD observes in General Six of UNCTAD: "International trade is one of the most important factors in economic development. It should be governed by such rules as are consistent with the attainment of economic and social progress and should not be hampered by measures incompatible therewith".

12. From a study on the arbitration laws of the member States of the PTA it was found that the national laws studied do not address themselves to international commercial arbitration because they were basically designed for the arbitration of domestic commercial disputes. See Report of the Seminar on International Trade Law, Preferential Trade Area for Eastern and Southern African States/United Nations Commission on International Trade Law, Regional Seminar, Maseru-Lesotho 25-30 July 1988, p.18. 
legal materials is often very difficult. Harmonisation of commercial laws and practice would ensure that whether litigation is in State $X$ or in State $Y$, the courts seized of the matter will apply the same governing law.

In addition, a number of issues arise in intraregional trade which do not present themselves in domestic commercial transactions. The parties involved in the transaction may have had no previous contact with each other. In a sales contract, for instance, this may mean that the seller is not familiar with the financial standing of the buyer. He or she has less opportunity for inspecting the goods before purchase or delivery. The delivery of the goods into the possession of the buyer, in intraregional trade, often necessitates carriage of goods by air, rail, road or sea over several national boundaries. Intraregional trade will require insurance and payment arrangements that involve arrangements covering more than one State. In many African jurisdictions, it may be difficult to find well developed legal rules governing some of these aspects of commercial transactions. Several areas, in addition to tariffs and customs duties, can be identified as requiring significant progress towards harmonisation. These include the law of sale of goods; the law relating to the supply and erection of plant and machinery in member States; and laws relating to bills of exchange, bankers' commercial letters of credit and guarantees, investment protection, trademarks and franchising, licensing of technology, distribution agreements, agency contracts, bankruptcy, security interests, mergers and acquisitions; and the law of commercial arbitration. All these areas of the law play an important facilitating role, and, if they are not harmonised, will tend to impede intraregional trade.

\section{TECHNIQUES TO HARMONISE COMMUNITY TRADE LAWS}

HITHERTO there have been no efforts aimed at integrating or harmonising any branch of African law and, consequently, no examples of the African experience can be used. The methods examined here have been used elsewhere in the world and it is suggested may serve as examples in the African context. The integration of law can be advanced using a variety of methods, ${ }^{13}$ but a review of harmonisation work reveals that in essence three methods have been adopted to further the progressive unification and harmonisation of laws in other jurisdictions. The first is the introduction of normative rules devised and elaborated within the framework of a treaty. ${ }^{1+}$ The normative rules themselves could be of three different kinds. One kind is the approach of adopting detailed uniform provisions for the substantive resolution of problems. Another approach

13. On methods of international unification, see. Report of the American Bar Association Special Committee on International Private Law (1961). p.6 and (1968-70) I United Nations Commission on International Trade Law, Ycarbook 39-40.

14. This would involve the elaboration of a convention to be adopted by community members, e.g. On the issue of sales law. 
is that of adopting conflicts of law rules, which envisages not uniform substantive rules but uniform reference to a particular body of law in all cases, i.e. rules relating to choice of competing substantive laws applicable to a particular transaction, and rules determining the competence of courts in particular litigation. ${ }^{15}$ The third approach is the constitutional approach, which seeks to specify general uniform standards within which particular resolutions are possible. This is where, for instance, a treaty provides that States will enact the necessary legislation to implement, within specified limits, the policies embodied in the treaty."

The second method of harmonisation, which is, in effect, an alternative to the first, is the formulation of model laws to serve as guides for local adaptation and uniform laws to be incorporated by States into their legislation. ${ }^{17}$ The model law method has the advantage that it permits substantial uniformity without requiring, as a treaty normally does, exact equivalency. It does, however, have the disadvantage that in the process of national implementation the uniformity achieved with such difficulty at the time of the elaboration of the model law may be lost.

The third technique is the formulation of commercial customs and practices, founded upon the usages of the commercial community with the aim of achieving standardisation. This would involve recommendations of standard practices, studies of national laws with a view to finding the minimum common rules that could be generally acceptable on a regional basis. Illustrations of this third method are the Incoterms 1953 and 1990, the Uniform Customs and Practice for Documentary Credits prepared by the International Chamber of Commerce (ICC), the various General Conditions of Sale and Standard Forms of Contract sponsored by the Economic Commission for Europe (ECE) and the Civil Conditions of Contract 1987 developed by the Fédération Internationale des Ingénieurs Conseils (FIDIC). ${ }^{18}$

Essential differences exist between the methods described above. The first and second are applied by virtue of the authority of the State, whereas the third is founded upon the autonomy of the will of the parties who adopt the customs and practices as the regime applicable to the individual transaction at hand. Experience in other regional economic communities has shown that each of these methods is essential to further the regional unification of trade law and commercial practices and, furthermore, that each complements the other. ${ }^{19}$ It is therefore evident

15. Sec Hilding Eck, The Swedish Conflicts of Laws (1965), p.272.

16. Sce UN Commission Yearbook, op. cil. supra n.13.

17. An example of this would be the UNCITRAL Model Law on International Commercial Arbitration.

18. See Fédération Internationale des Ingénieurs Conseils. Conditions of contracts for works of Civil Enginecring Construction (Parts I \& II). 1987.

19. See F. Mancini, "The Incorporation of Community Law into the domestic laws of member States of the European Communities". International Law in Practice: acts and 
that harmonisation of commercial laws and practices in the African Economic Community will require that all of the three methods described above should be actively pursued. All three methods can be pursued within the context of the African Economic Treaty.

In addition to the methods described above, the Treaty has empowered various organs of the Community to take legislative measures and make decisions in relation to the implementation of the Treaty. Article 8 of the Treaty, for instance, empowers the Assembly to take any action under the Treaty to attain the objectives of the Treaty and on the recommendation of the Council of Ministers, take decisions and make directives concerning the regional economic communities in order to ensure the realisation of the objectives of the Community. The decisions of the Assembly are binding on member States and organs of the Community as well as on Regional Economic Communities. ${ }^{21}$ The other organ of the Community, the Council of Ministers, has power to make recommendations to the Assembly on any action aimed at attaining the objectives of the Community. ${ }^{21}$ Under Article 13 the Council is empowered to enact regulations. Such regulations are binding on member States, subordinate organs of the Community and Regional Economic Communities after their approval by the Assembly. These are important powers which can be used to further the harmonisation of law and trade practices within the Community region. Experience in other Regional Economic Communities has shown that this can be done in three ways: the first method is by substitution, i.e. in so far as the Community member States have devolved power to the Community; uniform laws adopted by the Community would occupy the place and rank in the national systems of the legislation for which they are gradually substituted. The Community, through directives, could also require amendments to national laws to meet Community requirements. Thirdly, through directives, the Community regulations could co-ordinate the process of unification..$^{22}$ In this case it would not require the legislatures of the member States to make changes, but would confine itself to ordering the effects of their legislation in such a manner as to reduce any tendency to create discrimination against particular categories of persons.

proceedings of the 3rd Congress on Private Law held by the International Institute for the Unification of Private Law (Rome. 7-10 September 1987). p.13.

20. It can. under Art.8(h) on the recommendation of the Council, take decisions and directives concerning the regional economic communities in order to ensure the realisation of the objectives of the Community. Sec Treaty Establishing the African Economic Community. supra n.4.

21. See Treaty Establishing the African Economic Community, idem. Arts.11(a) and $13(1)(2)(3)$.

22. This is used in the EC. See K. Lipstein. Harmonisation of Private International Law by the EEC, (1978). 
For uniform law to have domestic effect it must be enacted or existing legislation amended. The Treaty of the Community contains provisions concerning the incorporation of laws into national systems. Under Article 5, member States undertake to create favourable conditions for the development of the Community and the attainment of its objectives, particularly in harmonising their strategies and policies. They are to refrain from any unilateral actions that may hinder the attainment of the objectives of the Community. In addition, each member State, in accordance with its constitutional procedures, promised to take all measures to ensure the enactment and dissemination of such legislation as may be necessary for the implementation of the provisions of the Treaty..$^{23}$ This process would, of course, have to be achieved by means of legislative approval and official publication in accordance with the rules in each system which govern the implementation of international agreements. It must be realised that, despite these provisions, the regulations and directives may encounter several obstacles in the individual States. Obstacles to the direct and uniform application of regulations may be created by national legislatures through delays in the adoption of the needed implementing and amending measures or by the adoption of measures that conceal the Community nature of the rules concerned. Other problems derive from the conflicts which arise between Community regulations and pre-existing or subsequent ordinary domestic laws. With regard to the directives, the most delicate question concerns the possibility that they may be given direct effect and thus invoked before national courts, even in the absence of implementing legislation. The search for a solution to all these problems is a matter of the utmost importance to the proper functioning of the Community institutions.

It must be pointed out that the unification process, in order for it to be successful, requires consultation with and participation by business groups, bankers, brokers, merchants and other experienced and expert people. This is to ensure that the rules adopted have a sound basis in the relevant business practices and customs of the Community and that the rules are sound, practical and meet the needs of those affected. In fact, such groups can provide the impetus for the harmonisation that is needed in the Community.

\section{INTERNATIONAL ORGANISATIONS AND THE HARMONISATION PROCESS}

IN the efforts to elaborate texts designed to provide uniform commercial laws for the Community, several precedents can be drawn from the work of international organisations in the field of the unification of inter-

23. The Treaty Establishing the African Economic Community, supra n.4, Art.5(1)(2)(3). 
national trade law. In some cases the adoption of a global text might, in fact, bring about the desired unification without the need to elaborate a separate regional text. There are several organisations working in this field. The leading body is the United Nations Commission on International Trade Law (UNCITRAL). UNCITRAL was established by the General Assembly in 1966. ${ }^{2+}$ Its mandate is to further the progressive harmonisation and unification of the law of international trade. The Commission has elaborated several conventions and Model laws of very high standard. These include the Convention on the Limitation Period in the International Sale of Goods (New York, 1974), the United Nations Convention on Contracts for the International Sale of Goods (Vienna, 1980), the United Nations Convention on the Carriage of Goods by Sea (Hamburg. 1978), the Convention on the Liability of Operators of Transport Terminals in International Trade (Vienna, 1991) and the United Nations Convention on International Bills of Exchange and International Promissory Notes (New York, 1988). In the field of arbitration, it has developed the UNCITRAL Arbitration Rules (1976), the UNCITRAL Conciliation Rules and the UNCITRAL Model Law on International Commercial Arbitration.".

The United Nations Conference on Trade and Development (UNCTAD) has been engaged in examining the economic, commercial and development aspects of the industrial property system, patents and trade marks. In addition it has studied, on a comparative basis, the different minimum standards which are applied, at the national or international level, by professional associations of shipping agents in order to consider what scope exists for the development of common guidelines for nonmandatory minimum standards for all those involved in the work of shipping agents and to prepare a draft set of standards. It has also been engaged in the development of model rules for multimodal container tariffs which could be used in establishing the terms and conditions of multimodal transport containers. It has further been involved in work in the field of charterparties, marine insurance and maritime fraud. ${ }^{20}$ The World Intellectual Property Organisation (WIPO) and the United Nations Educational and Scientific Organisations (UNESCO) have been jointly engaged in a study designed to recommend solutions for national laws for the protection of computer programs, for works created by employee-authors. They are also engaged in studying the copyright law

24. UNGA Res.2205 (XXI). 1966. For a description of the work of UNCITRAL see United Nations Commission on International Trade Law. (1986).

25. The copies of the conventions and model laws can be obtained directly from the organisation concerned or the United Nations Treaty Series.

26. UNCITRAL. Twenty-second session. Current Activities of International Organizations. Related to the Harmonization and Unification of Imernational Trade Law. Report of the Secretary-General, A/CN.9/324. 
aspects of the rental of phonograms and videograms of direct broadcasting satellites and of electronic libraries. WIPO is also engaged in drafting model provisions for legislation in the field of copyright. The Model provisions are intended to inspire and influence governments and legislators to improve their copyright laws and opt for solutions advocated therein; this will increase the degree of similarity among legislation in different States, whenever the special interests of a State do not require different solutions. ${ }^{27}$

The United Nations Industrial Development Organisation (UNIDO) has evolved a set of legal materials including model contracts and clauses, guidelines and checklists for contractual arrangements in the following fields: capital goods, agricultural machinery, iron and steel, fertilisers, petrochemicals, pharmaceuticals, leather and leather products, vegetable oils and salts, food processing, industrial financing, training of industrial manpower, wool and wool products and building materials. UNIDO has, in addition, carried out studies of investment laws in many parts of Africa and published booklets on each country. These booklets are designed to meet the special information needs of a potential investor, interested in investment prospects in a given developing country. Each of the booklets contains a brief account of the country, its people and resources, the basic infrastructure, the manner in which the economy has developed over the last few years, its industry, the policies and procedures for industrial licensing and transfer of know-how and the facilities which are available to anyone interested in investing in the country. $2 *$

In addition, the various United Nations Regional Economic Commissions, in their efforts to assist in raising the level of economic activity in their respective regions and to strengthen economic relations on both an intraregional and an interregional level, have developed a number of useful texts. For instance, the Economic Commission for Africa (ECA) has undertaken studies of national legislation dealing with trade in related fields such as insurance law and investment codes whose purpose is to enable conclusions to be drawn regarding measures for the harmonisation of such legislation, especially on a sub-regional basis. In connection with the foregoing project, ECA promotes the adoption of the Brussels Tariff Nomenclature among the member States of the ECA. The ECA reviews legislation and practices with respect to investment incentives and industrial development, and has studied the question of harmonisation of these matters among the member States. In addition, studies have been initiated on the harmonisation of legislation concerning mari- 
time transport and on the constitutional and legal basis of public autonomous institutions and corporations. The ECA has also been working in the area of harmonisation and simplification export documents.

Other organisations working in the field of the harmonisation of law include the International Institute for the Unification of Private Law (UNIDROIT). ${ }^{29}$ The work of this Institute has formed the basis of a number of conventions in international trade. Apart from elaborating conventions, UNIDROIT is engaged in research into ways and means of advancing the task of unification. Another organisation is The Hague Conference on Private International Law, ${ }^{3(1)}$ which has developed a number of conventions in the attempt to unify conflicts rules in international trade law. In addition to these world-wide organisations, a number of regional intergovernmental organisations and groupings and nongovernmental organisations have elaborated texts on international trade and commercial practice which would serve as useful precedents to the African Treaty. Unification of trade laws and commercial practice have made great progress in certain parts of the world, for instance, in the Scandinavian region.

\section{THE LEGAL FRAMEWORK IN THE COMMUNITY TREATY FOR THE HARMONISATION OF LAW}

IN Article 5 of the Treaty member States undertake to create favourable conditions for the development of the Economic Community. Each member State is required to take all necessary measures to ensure the enactment and dissemination of such legislation, as may be necessary for the implementation of the provisions of the Treaty. In Article 29 member States of each Regional Economic Community are required progressively to eliminate customs duties, other restrictions or prohibitions, administrative trade barriers as well as all other non-tariff barriers and, in Article 30 , are required to eliminate customs duties. As has already been pointed out, several organs have been created under the Treaty to take legislative measures to implement the programme of the Treaty, and decisions of these organs are binding on member States, on organs of the Community, as well as on the Regional Economic Communities. ${ }^{31}$

The Community Treaty does not expressly set up, as one of its objectives, the unification of trade laws in the Community. Neither does it set up, among its specialised technical committees, one to deal with legal issues and, in particular, the harmonisation of trade laws and commercial

29. The Institute was founded in 1926 for the purpose of harmonising and co-ordinating the rules of private law of the different States, with a view to promoting gradually the adoption of a uniform system of private law.

30. The purpose of the organisation, as stated in its charter approved in 1951, is to work for the progressive unification of private international law.

31. See Arts.8, 11, 14, 18, and 25 for the various organs established under the Treaty. 
practices in the Community. Article 25, which deals with the establishment of specialised Technical Committees, establishes a total of seven such Committees. ${ }^{32}$ They are as follows: the committee on rural economy and agriculture matters; the committee on monetary and financial affairs; the committee on trade, customs and immigration; the committee on industry, science and technology, energy, natural resources and environment; the committee on transport, communications and tourism; the committee on health, labour and social affairs and the committee on education, culture and human resources. The special Technical Committees will play an important role in the implementation of the objectives of the Community, as they are charged with, among other things, the preparation of projects and programmes for the Community; the supervision, follow-up and evaluation of the implementation of decisions taken by the organs of the Community; ensuring the co-ordination and harmonisation of projects and programmes; and submitting reports and recommendations on the implementation of the provisions of the Treaty.

As has been stated, none of the committees is a legal committee. The fact that there is no legal committee among the Technical Committees, provided for under Article 25, means that there is no organ specially charged with the task of elaborating the various legal texts for the several protocols to be done under the Treaty or with furthering co-operation in the development of the Community's trade laws and commercial practices and providing for their progressive unification. This means that the work of harmonisation of trade laws will be carried on in a piecemeal manner by any one of the several committees that may wish to unify a particular area of the law. This is unsatisfactory in view of the importance of the need to harmonise trade laws and commercial practices in the Community. It is suggested that a committee with this specific responsibility be established, with the following functions: the preparation of studies and recommendations on problems concerning the unification and harmonisation of the Community trade law, including comparative analyses of national legislation; studies and research on particular topics at the request of the Assembly; preparation of trade conventions, model laws and uniform laws; promotion of the codification and wider acceptance of regional trade terms, customs and practices; and the promotion of ways and means of ensuring a uniform interpretation and application of regional conventions and uniform laws in the field of the law of international trade and commercial practice. It could also collect and disseminate information on national legislation and modern legal developments in the field of trade law.

32. See Treaty Establishing the African Economic Community, supra n.4. 
The proposed committee could also be concerned with the promotion of training and research in the field of integration law, in particular at African universities and research institutions. The process of integration has many dimensions-political, economic, judicial, cultural, scientific, technological. All help to determine the social structure that could contribute to the integration process. Nevertheless, there is a tendency to associate the concept of integration only with the economic dimension and the judicial implications that this carries. There are other areas which are also of importance and need to be addressed. Development depends to a great degree on a State's capacity for absorbing or creating technologies, and the development of its human resources. This is why research and training are so important. Research and training have a fundamental part to play in the task of achieving greater integration between African States. In response to the complex problems of integration, African research institutes and universities must be encouraged to co-operate in the search for solutions. They can contribute substantially in the promotion of academic activity in the integration field and generating a flow of knowledge, analysis and suggestions that would be of great value to Africa's integration process. African researchers can make a contribution to the creation of an independent African thought process, in regard to the continent's integration process.

There is a mechanism by which the absence of a technical committee on the harmonisation of trade laws and commercial practices can be remedied. Article 25 of the Treaty permits the Assembly, whenever it deems appropriate, to restructure existing committees or establish other committees. ${ }^{33}$ It is our view that this should be done at the earliest possible opportunity. As earlier pointed out, a modern legislative framework is the necessary foundation for sound intraregional trade. The creation of such a framework is a complex and long-term endeavour which needs to be organised properly.

\section{CONCLUSION}

THIS paper has discussed the harmonisation of laws in the African Economic Community, first by examining the relevance of the subject to the attainment of the objectives of the African Economic Community and, later, examining ways in which harmonisation could be achieved and the institutional framework necessary for its attainment. Since one of the purposes of unification and harmonisation of trade laws and commercial practices is to bring about changes in national laws, the difficulties of this endeavour should not be underestimated. However, the matters relating to the unification of trade laws and commercial practices are primarily of a technical nature. It should, therefore, be less difficult to adopt regional

33. Idem, Art.25. 
rules on such matters than it is with respect to such matters as family law, succession, personal matters and other subjects deeply rooted in national or religious traditions. The common interest of all States to increase intraregional trade should also act as an incentive towards progress in the field. Care must be taken to ensure that unification, when it is formulated, is not at the lowest common denominator. There is no merit in harmonisation if it results in the adoption by a group of States of the legal concepts acceptable to the least progressive among them.

Ways must also be found, after the adoption of harmonised laws, to encourage courts to interpret unification legislation in a manner that fosters integration. One way of doing this is through seminars and a curriculum in law schools which would encourage regional thinking and foster an appreciation of regional goals. The actual behaviour of the national courts is decisive in furthering harmonisation. It is in the national courts that divergent development of harmonised national laws can evolve, from the very outset, despite all endeavours at integration and harmonisation. Accordingly, if African integration by legal harmonisation is to be furthered, national courts would have to rethink their interpretation of the application of Community-level directives, and Community institutions must think of ways to facilitate this. If this were to happen, it would make a decisive contribution towards changing behaviour as well as thought. In short, this is the crucial point. It is also important to point out that the implementation of many of the Community objectives, including that of harmonising trade law and commercial practices, will require high-level expertise in every field concerned. Availability of trained personnel and resources are of the utmost importance because when one speaks of harmonisation of trade laws and commercial practices one is speaking about expenditure, research, implementation and high-quality elaboration of instruments to bring about the desired results. 